Article

\title{
Notes on the Potential for the Concentration of Rare Earth Elements and Yttrium in Coal Combustion Fly Ash
}

\author{
James C. Hower ${ }^{1, *}$, John G. Groppo ${ }^{1}$, Kevin R. Henke ${ }^{1}$, Madison M. Hood ${ }^{1}$, Cortland F. Eble ${ }^{2}$, \\ Rick Q. Honaker ${ }^{3}$, Wencai Zhang ${ }^{3}$ and Dali Qian ${ }^{1,4}$
}

1 Center for Applied Energy Research, University of Kentucky, 2540 Research Park Drive, Lexington, KY 40511, USA; E-Mails: john.groppo@uky.edu (J.G.G.); kevin.henke@uky.edu (K.R.H.); madison.hood@uky.edu (M.M.H.); dali.qian@uky.edu (D.Q.)

2 Kentucky Geological Survey, Lexington, KY 40506, USA; E-Mail: eble@uky.edu

3 Department of Mining Engineering, University of Kentucky, Lexington, KY 40506, USA; E-Mails: rick.honaker@uky.edu (R.Q.H.); wencai.zhang@uky.edu (W.Z.)

4 Electron Microscopy Center, Department of Chemical and Materials Engineering, University of Kentucky, Lexington, KY 40506, USA

* Author to whom correspondence should be addressed; E-Mail: james.hower@uky.edu; Tel.: +1-859-257-0261.

Academic Editor: Panagiotis Voudouris

Received: 20 May 2015 / Accepted: 16 June 2015 / Published: 23 June 2015

\begin{abstract}
Certain Central Appalachian coals, most notably the Fire Clay coal with a REY-enriched volcanic ash fall tonstein, are known to be enriched in rare earth elements. The Fire Clay tonstein has a greater contribution to the total coal + parting REY than would be inferred from its thickness, accounting for about $20 \%-35 \%$ of the REY in the coal + parting sequence. Underground mining, in particular, might include roof and floor rock and the within-seam partings in the mined product. Beneficiation, necessary to meet utility specifications, will remove some of the REY from the delivered product. In at least one previously published example, even though the tonstein was not present in the Fire Clay coal, the coal was enriched in REY. In this case, as well as mines that ship run-of-mine products to the utility, the shipped REY content should be virtually the same as for the mined coal. At the power plant, however, the delivered coal will be pulverized, generally accompanied by the elimination of some of the harder rock, before it is fired into the boiler. Overall, there are a wide range of variables between the geologic sample at the mine and the power plant, any or all of which could impact the concentration of REY or other critical materials in the coal combustion products.
\end{abstract}


Keywords: lanthanides; critical materials; power plants; fly ash; coal

\section{Introduction}

Central Appalachian coals, in particular the Middle Pennsylvanian Fire Clay coal in Eastern Kentucky and Southern West Virginia, are known to be relatively enriched in rare earth elements (REE); or rare earth + yttrium (REY) if Yttrium is included. The Fire Clay coal stands out because it includes a volcanic ash-derived parting or tonstein [1], which has a high REY content [2,3]. Portions of the coal above and, in particular, below the tonstein are also enriched in REY [2]. In some cases where the tonstein is not present, the coal is still enriched in REY [3]. Comparing average ash-basis REYs from five major coals (Table 1, after Bragg et al. [4]), it can be seen that the Fire Clay coal and its correlatives have a higher total REY than the other coals.

Table 1. Averages (ash-basis ppm) of rare earth elements and yttrium for five major eastern

Kentucky coals. Based on data compiled by [4]. The Clintwood Gd average contains one value of 173 ppm, far higher than the other Gd values. Avg: average; st dev: standard deviation.

\begin{tabular}{|c|c|c|c|c|c|c|c|c|c|c|c|c|c|c|c|c|c|c|c|}
\hline \multirow{2}{*}{\multicolumn{2}{|c|}{ Coal Bed }} & \multirow{3}{*}{$\begin{array}{c}\text { Dry Ash } \\
11.28\end{array}$} & \multicolumn{15}{|c|}{ Whole Coal Basis } & \multicolumn{2}{|c|}{ Ash Basis } \\
\hline & & & Y & La & $\mathrm{Ce}$ & Pr & Nd & Sm & $\mathbf{E u}$ & Gd & $\mathbf{T b}$ & Dy & Ho & $\mathbf{E r}$ & Tm & Yb & Lu & $\mathbf{Y}+\mathbf{R E E}$ & $\mathbf{Y}+\mathbf{R E E}$ \\
\hline Coalburg & avg & & 8.7 & 11.1 & 21.2 & 6.5 & 11.3 & 1.9 & 0.4 & 1.7 & 0.4 & 2.1 & 0.6 & 1.0 & 0.4 & 1.2 & 0.2 & 68.6 & 668.3 \\
\hline$($ no. $=104)$ & st dev & 5.41 & 4.3 & 5.0 & 9.1 & 3.9 & 5.3 & 0.7 & 0.2 & 1.2 & 0.1 & 1.4 & 0.3 & 0.6 & 0.2 & 0.4 & 0.1 & 26.1 & 241.6 \\
\hline Leatherwood & avg & 11.02 & 10.0 & 13.1 & 24.7 & 6.0 & 13.8 & 2.2 & 0.5 & 1.8 & 0.4 & 2.2 & 0.6 & 1.1 & 0.4 & 1.4 & 0.2 & 78.3 & 789.5 \\
\hline$($ no. $=38)$ & st dev & 6.22 & 5.2 & 8.0 & 13.8 & 3.9 & 9.9 & 1.2 & 0.2 & 1.2 & 0.2 & 1.4 & 0.3 & 0.9 & 0.2 & 0.6 & 0.1 & 40.3 & 287.2 \\
\hline Fire Clay & avg & 11.46 & 11.8 & 17.9 & 33.9 & 7.1 & 17.9 & 2.9 & 0.5 & 2.7 & 0.6 & 2.8 & 0.6 & 1.4 & 0.4 & 1.7 & 0.2 & 102.5 & 921.9 \\
\hline$($ no. $=41)$ & st dev & 5.64 & 8.1 & 9.9 & 18.9 & 4.8 & 15.6 & 1.4 & 0.2 & 3.4 & 0.3 & 2.0 & 0.4 & 1.2 & 0.3 & 0.7 & 0.1 & 58.8 & 319.9 \\
\hline Pond Creek & avg & 7.24 & 5.0 & 6.4 & 12.2 & 4.2 & 6.0 & 1.1 & 0.3 & 1.1 & 0.2 & 1.3 & 0.4 & 0.6 & 0.2 & 0.8 & 0.1 & 39.8 & 550.5 \\
\hline$($ no. $=46)$ & st dev & 4.13 & 3.2 & 5.4 & 9.5 & 2.9 & 6.7 & 0.8 & 0.2 & 1.0 & 0.1 & 0.8 & 0.2 & 0.5 & 0.1 & 0.4 & 0.0 & 29.4 & 213.2 \\
\hline Clintwood & avg & 6.89 & 5.4 & 7.2 & 13.1 & 3.6 & 6.9 & 1.2 & 0.3 & 1.4 & 0.2 & 1.2 & 0.3 & 0.6 & 0.2 & 0.8 & 0.1 & 42.5 & 676.9 \\
\hline$($ no. $=40)$ & st dev & 4.05 & 2.8 & 4.5 & 8.1 & 2.1 & 4.4 & 0.7 & 0.2 & 2.1 & 0.1 & 0.6 & 0.2 & 0.5 & 0.1 & 0.4 & 0.0 & 21.5 & 271.0 \\
\hline all & avg & 9.91 & 7.9 & 10.5 & 20.1 & 5.6 & 10.3 & 1.8 & 0.5 & 1.7 & 0.4 & 1.9 & 0.6 & 1.0 & 0.4 & 1.2 & 0.2 & 63.2 & 687.6 \\
\hline$($ no. $=788)$ & st dev & 5.60 & 4.7 & 7.3 & 14.1 & 4.1 & 8.1 & 1.7 & 1.4 & 2.1 & 1.4 & 1.8 & 1.4 & 1.5 & 1.4 & 1.5 & 1.4 & 37.1 & 296.2 \\
\hline
\end{tabular}

The potential for the concentration of REY in coal combustion products (CCPs) has been investigated in a number of coal fields [3,5-7]. In principal, the REY are conserved in the combustion process, meaning that they are not among the volatile elements and not particularly vulnerable to loss with flue gas. The concentration of REY in the feed coal should be proportional to the REY in the coal combustion products, therefore, coals with high REY, such as the Pennsylvanian Fire Clay coal in Eastern Kentucky, should yield CCPs with high REY [2,3]. Indeed, for the Fire Clay-coal-derived CCP's investigated by Mardon and Hower [3], the REY content of the bottom ash did not differ greatly from the concentrations in the fly ash and the REY concentrations in fly ashes from individual rows in the ash collection system were similar, all generally within $10 \%-20 \%$ of each other. In contrast, volatile trace elements can vary by several $100 \%$ from the first electrostatic precipitator row to the last row [3]. 
For the current investigation, coal and a composite fly ash were collected at two power plants. In addition, a composite bottom ash sample was collected at one plant. In both cases, the power plant was burning a coal blend dominated by the eastern Kentucky Fire Clay coal.

\section{Methods}

The samples were analyzed for moisture and ash following American Society for Testing and Materials (ASTM) standard methods. The REY content was analyzed by Inductively Coupled Plasma-Mass Spectroscopy using sinter methods adapted from U.S. Geological Survey procedures [8].

Elemental studies of selected samples were conducted on a Zeiss EVO-MA10 SEM (Zeiss, Jena, Germany), coupled with back-scatter electron (BSE) detector and a Bruker energy-dispersive (EDS) detector, which was operated at $20 / 25 \mathrm{keV}$. In some cases, potential mineral grains were first identified using optical microscopy in the CAER Applied Petrology Laboratory. For this purpose, the ash was mounted in 2.54-cm diameter pellets and prepared to a 0.05 -micron final polish. The pellets were examined using reflected-light, oil-immersion optics at a final magnification of $500 \times$. Promising grains were circled using a diamond-tip indenter and photographed using a Spot Insight 4 digital camera.

Selected samples were examined by powder X-ray diffraction (XRD) at the University of Kentucky Center for Applied Energy Research. If required, the samples were ground by hand in a ceramic mortar and pestle just before XRD analysis. The powdered samples were then dry mounted in aluminum holders. The samples were scanned at $8^{\circ}-60^{\circ} 2 \theta$ with copper K- $\alpha$ radiation on a Philips X'Pert diffractometer (model PW3040-PRO, Amsterdam, The Netherlands) operating at 45 kilovolts (kV) and 40 milliamps $(\mathrm{mA})$. Crystalline substances or "minerals" were identified in the diffractograms with an International Centre for Diffraction Data (ICDD, Newtown Square, PA, USA) powder diffraction (PDF) database.

Coal and fly ash petrology was using oil-immersion, reflected-light optics on epoxy-bound 2.54-cm diameter particulate pellets prepared to a final 0.05-micron polish. Maceral nomenclature followed International Committee for Coal Petrology (ICCP) [9,10] and fly ash nomenclature followed Hower [11].

\section{Results and Discussion}

The Mardon and Hower [3] study has proven to be something of a benchmark for US-based REY-enrichment investigations. The study was originally planned as a single-seam, single-mine investigation of the partitioning of mercury; the added focus on rare earth elements was serendipitous, a function of the use of a Fire Clay coal correlative as the source coal. There are unique features of the study which need to be considered when comparing the results with REY concentrations in fly ash from other power plants. Unlike most other Fire Clay sites, the Mardon and Hower [3] Fire Clay coal site did not have the REY-rich tonstein. Instead, the part of the coal where the parting would usually be found had a high concentration of REY. In one sense, the presence or absence of the tonstein in the coal made no difference since the utility contracted to purchase unbeneficiated, run-of-mine coal from the mine. As long as the run-of-mine coal met the contracted ash/sulfur/heating value (and, in some cases, other parameters, such as chlorine and grindability) specifications, it would have been shipped to the utility. The utility does pulverize the coal, so some rock would have been rejected by the pulverizer. In contrast, the underground mines producing Fire Clay coal will typically mine some of the roof and floor rock in addition to all of the partings. The coal + rock is beneficiated, leaving the REY-enriched 
tonstein with the refuse at the power plant. Rock shipped with the coal to the power plant might be rejected in pulverization, as noted above. Therefore, the Mardon and Hower [3] Fire Clay coal would have had a higher concentration of REY than the Fire Clay coal typically burned by power plants.

In order to understand the influence of the different geologic settings and mining/beneficiation scenarios, we examined three examples of the distribution of REY within the Fire Clay coal bed (Table 2). In the KCER-5499 to -5504 sequence from the Mardon and Hower [3] study, the flint clay parting is absent but the REY signature is present in the lower four benches of the coal. The KCER-4754 to -4767 is an example of the flint clay tonstein directly overlaying coal while the tonstein overlays an illitic clay in the KCER-4706 to -4714 sequence [2]. In both of the latter two sequences, the coal benches, with one exception, have a higher ash-basis REY than the flint clay. The flint clay parting, however, always has higher whole-sample REY content than the coals. In the KCER-4754 to -4767 sequence, the flint clay, with less than $10 \%$ of the total seam thickness, accounts for over $20 \%$ of the total REY. Therefore, the flint clay parting, despite having a REY concentration diluted by the abundance of minerals with negligible REY content, still makes a significant contribution of REY to the overall amount of REY in the entire coal + parting sequence.

For the current study, the power plant feed coals have different sources, as indicated by the vitrinite maximum reflectances (Table 3). The higher reflectance (higher rank) of the plant $\mathrm{W}$ feed coal is known to have been mined in Southern Leslie County, Kentucky, closer to the higher-rank portions of the coalfield. The plant I coal was mined further to the north-northwest, a lower rank region. The maceral percentages are not unique enough to be diagnostic indicators of the coal source.

The fly ash petrology (Table 4) is dominated by glass, much of it rounded, as is typical of pulverized-coal-derived fly ashes, but with a small percentage of angular glassy particle, as seen on the left-center of Figure 1. Fly ash carbons, including both inertinite passed along from the feed coal and neoformed carbons from the melting and re-polymerization of macerals, are significantly more abundant in the plant I fly ash than in the plant $\mathrm{W}$ ash.

The REY concentrations in the feed coal and combustion products for the two power plants are shown in Table 5. As noted above, the coal blends were dominated by Fire Clay coal. However, the utilities, in contracting for the coal, did specify that the Fire Clay should constitute the majority of blend, but they had less control of the coal and mine selection process than was present for the Mardon and Hower [3] study. The feed coal REY concentrations are lower than published REY values for the Fire Clay coal (for example, the average Fire Clay REE and REY in Table 1 from Bragg et al. [4] and Table 2 values from Hower et al. [2] and Mardon and Hower [3]). Caution must be exercised in comparing geologic samples to the mined, beneficiated (or not beneficiated), and shipped product. While thicker partings should be excluded from the geologic sample, even the thin partings could be beneficiated out of the coal destined for a power plant. As noted above, the objective of the beneficiation is to produce a coal product meeting or slightly exceeding the contract specifications. To date, for US coals and utilities, the REY concentration has not been a contracted parameter. In addition to the exclusion (or inclusion as misplaced material) of in-seam or of out-of-seam rock in the shipped product, the Fire Clay-derived REY concentration could also be diluted through the inclusion of other coals with lower REY concentrations. Despite these caveats, the ash-basis fly ash REY concentrations of 774 and 899 ppm, while lower than the range seen in the Mardon and Hower [3] fly ashes, are among the best REY concentrations observed in our studies to date. 
Table 2. Rare earth elements and yttrium for three distinct settings of the Fire Clay coal: (1) samples 5499-5504-no tonstein parting but high REY concentrations [3], (2) samples 4706-4714 — tonstein overlying an illitic clay parting [2], and (3) samples 4754-4767-tonstein without an illitic clay parting.

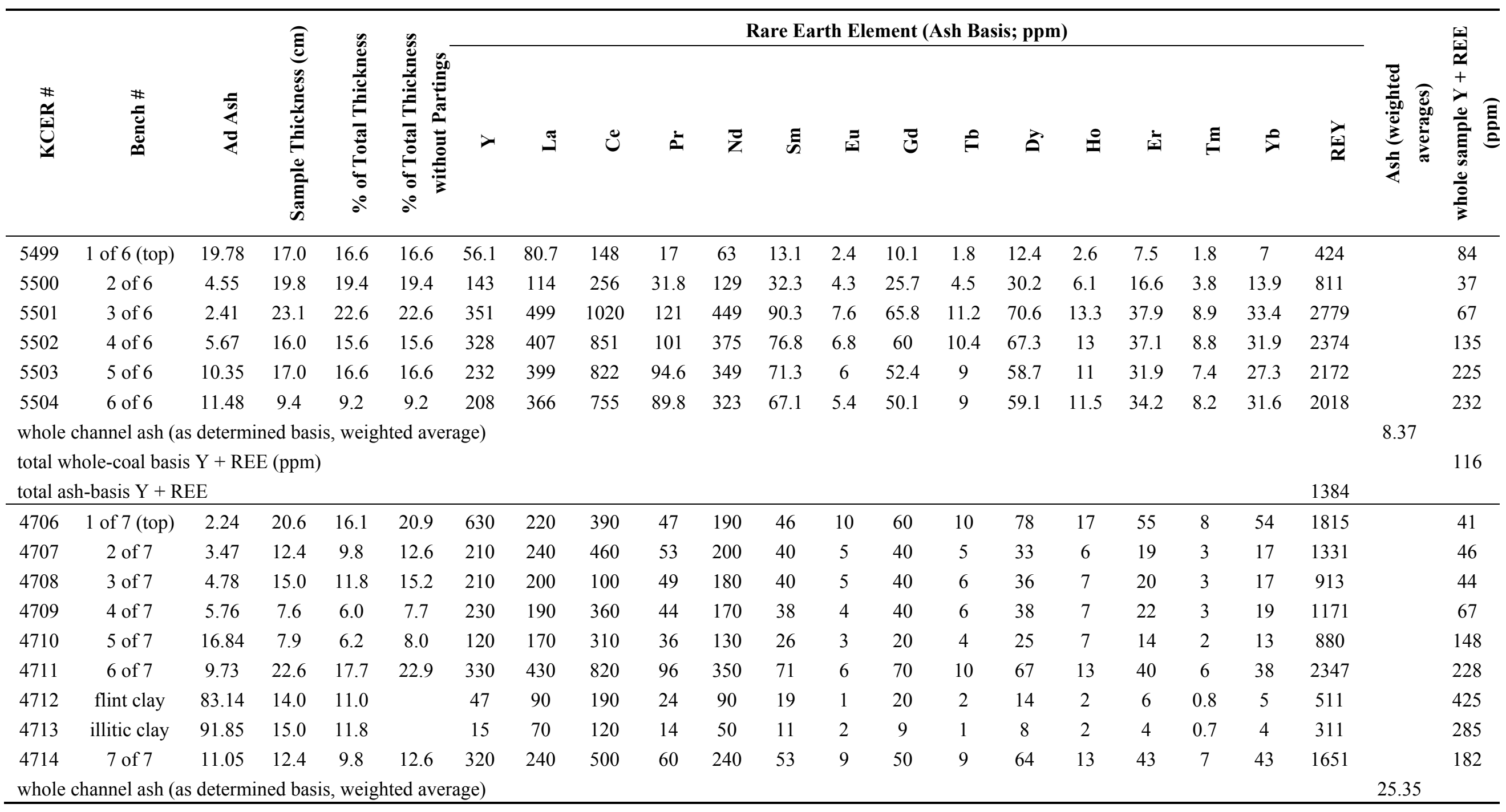


Table 2. Cont.

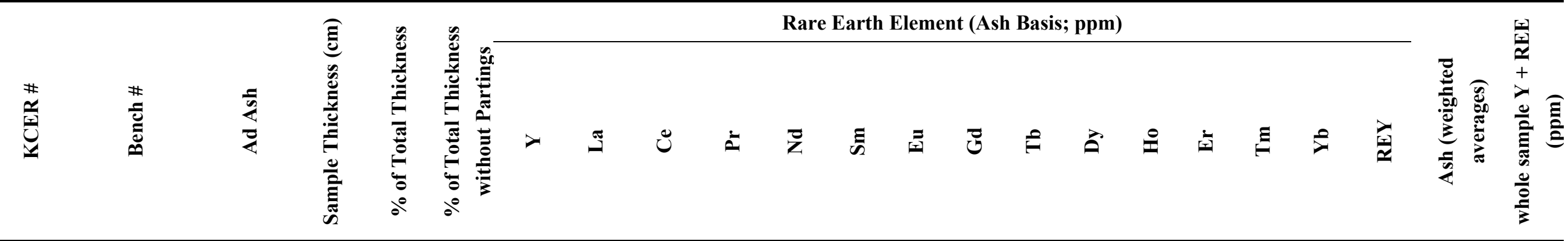

whole channel ash, excluding partings (as determined basis, weighted average)

7.05

total whole-coal-basis $\mathrm{Y}+\mathrm{REE}$ with partings (ppm)

168

total whole-coal-basis $\mathrm{Y}+\mathrm{REE}$ without partings (ppm)

$\%$ total whole-coal basis Y + REE without partings/\% total whole-coal basis Y + REE with partings

\begin{tabular}{ccccccccccccccccccccc}
\hline 4754 & 1 of 11 (top) & 3.87 & 10.4 & 8.3 & 9.2 & 390 & 140 & 270 & 33 & 130 & 36 & 8 & 40 & 9 & 58 & 12 & 36 & 5 & 33 & 1200 \\
4755 & 2 of 11 & 10.26 & 10.4 & 8.3 & 9.2 & 97 & 60 & 110 & 12 & 50 & 10 & 2 & 10 & 2 & 10 & 2 & 6 & 0.8 & 5 & 377 \\
4756 & 3 of 11 & 3.68 & 9.9 & 7.9 & 8.7 & 190 & 250 & 470 & 54 & 190 & 42 & 5 & 40 & 6 & 37 & 7 & 20 & 3 & 18 & 1332 \\
4757 & 4 of 11 & 13.14 & 13.0 & 10.3 & 11.4 & 79 & 140 & 240 & 28 & 90 & 20 & 3 & 20 & 3 & 18 & 4 & 11 & 2 & 10 & 668 \\
4758 & 5 of 11 & 6.58 & 9.4 & 7.5 & 8.3 & 210 & 180 & 370 & 44 & 160 & 36 & 4 & 30 & 6 & 35 & 6 & 19 & 3 & 17 & 1120 \\
4759 & 6 of 11 & 4.79 & 12.7 & 10.1 & 11.2 & 340 & 240 & 470 & 57 & 210 & 49 & 5 & 50 & 8 & 51 & 10 & 30 & 4 & 27 & 1551 \\
4760 & 7 of 11 & 10.29 & 18.0 & 14.3 & 15.9 & 200 & 270 & 500 & 58 & 200 & 44 & 4 & 40 & 7 & 46 & 9 & 30 & 5 & 29 & 1442 \\
4761 & flint clay & 83.85 & 12.4 & 9.9 & & 49 & 110 & 200 & 24 & 90 & 19 & 1 & 20 & 2 & 13 & 2 & 6 & 0.8 & 4 & 541 \\
4762 & 8 of 11 & 10.01 & 9.4 & 7.5 & 8.3 & 430 & 790 & 1500 & 100 & 660 & 150 & 13 & 130 & 22 & 130 & 25 & 75 & 11 & 72 & 4108 \\
4763 & 9 of 11 & 25.26 & 11.4 & 9.1 & 10.1 & 110 & 110 & 210 & 25 & 90 & 22 & 4 & 20 & 4 & 28 & 6 & 18 & 3 & 17 & 667 \\
4765 & 10 of 11 & 25.08 & 4.6 & 3.6 & 4.0 & 120 & 110 & 200 & 26 & 100 & 36 & 6 & 20 & 4 & 24 & 5 & 15 & 2 & 13 & 681 \\
4767 & 11 of 11 & 9.69 & 4.1 & 3.2 & 3.6 & 320 & 160 & 360 & 47 & 190 & 51 & 12 & 50 & 10 & 61 & 12 & 36 & 5 & 34 & 1348
\end{tabular}

whole channel ash (as determined basis, weighted average)

whole channel ash, excluding partings (as determined basis, weighted average) 
Table 3. Feed coal petrology. Macerals not encountered are not listed in the table. Note that the vitrinite maceral subgroups are totaled along with the total vitrinite percentage. The inertinite, liptinite, and mineral percentages are listed along with the individual percentages of the macerals and minerals. Vitrinite maximum (Rmax) and random (Rrandom) reflectances and their respective standard deviations are also listed for each coal.

\begin{tabular}{|c|c|c|c|c|c|c|c|c|c|c|c|c|c|c|c|c|c|c|c|c|c|c|c|c|c|}
\hline$\stackrel{\vec{E}}{\vec{a}}$ & 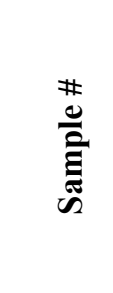 & & 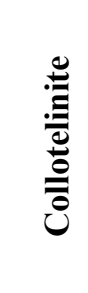 & 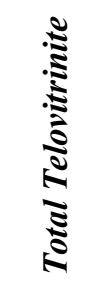 & 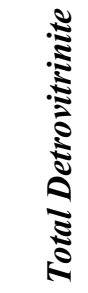 & 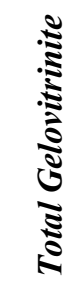 & 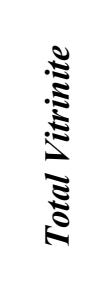 & 泀 & & 苞 & 㚔 & 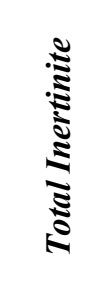 & 苟 & Ü: & 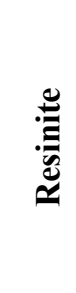 & 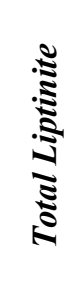 & 苞 & 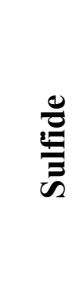 & 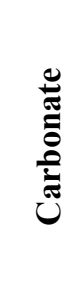 & $\stackrel{\grave{d}}{\overline{0}}$ & 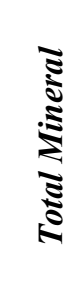 & $\stackrel{\Xi}{\tilde{I}}$ & $\frac{⿱ 乛 ⿻}{0}$ & 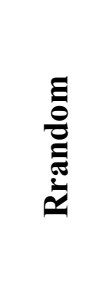 & $\frac{\vec{d}}{\tilde{E}}$ \\
\hline \multirow{2}{*}{ W } & \multirow{2}{*}{93931} & 10.4 & 35.6 & 46.0 & 11.4 & 8.0 & 65.4 & 9.0 & 7.4 & 5.4 & 0.2 & 22.0 & 8.0 & 0.6 & 0.6 & 9.2 & 2.8 & 0.6 & 0.0 & 0.0 & 3.4 & 0.91 & 0.06 & 0.84 & 0.06 \\
\hline & & 10.8 & 36.9 & 47.6 & 11.8 & 8.3 & 67.7 & 9.3 & 7.7 & 5.6 & 0.2 & 22.8 & 8.3 & 0.6 & 0.6 & 9.5 & & & & & & & & & \\
\hline \multirow{2}{*}{ I } & \multirow{2}{*}{93939} & 10.0 & 43.4 & 53.4 & 10.6 & 3.4 & 67.4 & 5.8 & 7.2 & 2.2 & 1.6 & 16.8 & 6.2 & 2.4 & 0.4 & 9.0 & 5.4 & 1.2 & 0.0 & 0.2 & 6.8 & 0.76 & 0.09 & 0.69 & 0.09 \\
\hline & & 10.7 & 46.6 & 57.3 & 11.4 & 3.6 & 72.3 & 6.2 & 7.7 & 2.4 & 1.7 & 18.0 & 6.7 & 2.6 & 0.4 & 9.7 & & & & & & & & & \\
\hline
\end{tabular}

Table 4. Fly ash petrology (volume percent; $\mathrm{t}=$ trace).

\begin{tabular}{ccc}
\hline Sample & 93932 & 93951 \\
Plant & Plant W & Plant I \\
Material type & fly ash & fly ash \\
glass & 89.6 & 64.5 \\
mullite & 0.0 & 2.0 \\
spinel & 1.2 & 8.5 \\
quartz & 2.0 & 0.0 \\
sulfide & 0.8 & 1.0 \\
rock fragment & $\mathrm{t}$ & 0.0 \\
isotropic coke & 0.4 & 6.5 \\
anisotropic coke & 4.8 & 13.5 \\
inertinite & 1.2 & 4.0 \\
\hline
\end{tabular}




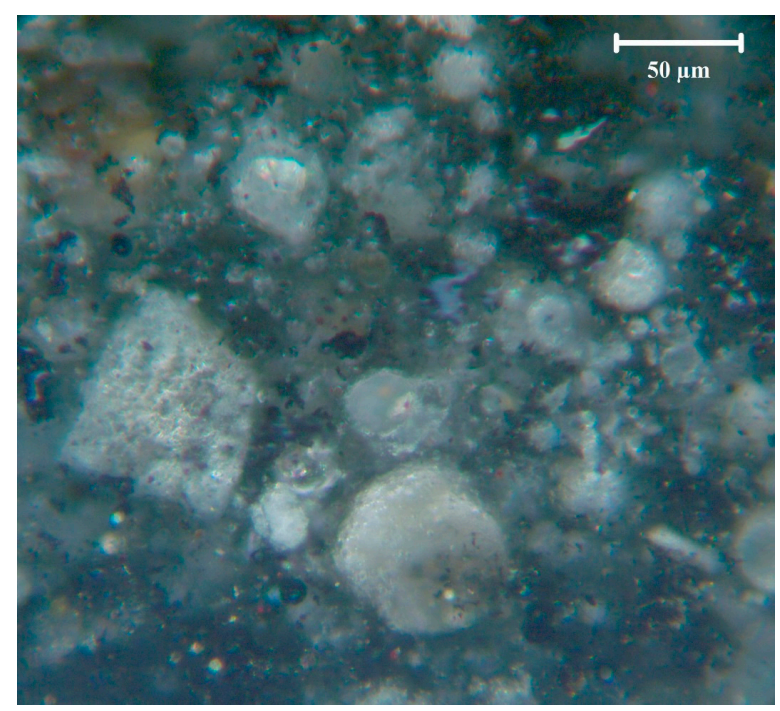

Figure 1. Plant W fly ash with both rounded and angular glass particles. Image 93932 FA 06.

An SEM image of fly ash from the plant $\mathrm{W}$ fly ash with the element analysis results is shown in Figure 2. Using Ce as a proxy for the entire REY suite, detectable amounts of REY are seen in what appears to be a Fe oxide. Hower et al. [12] and Dai et al. [7] have also demonstrated that REY can be detected in the fly ash glass, at least as part of the glass, if not as mineral phases included within the glass. REY elements were observed in the bottom ash glass from another sampling date at plant I.

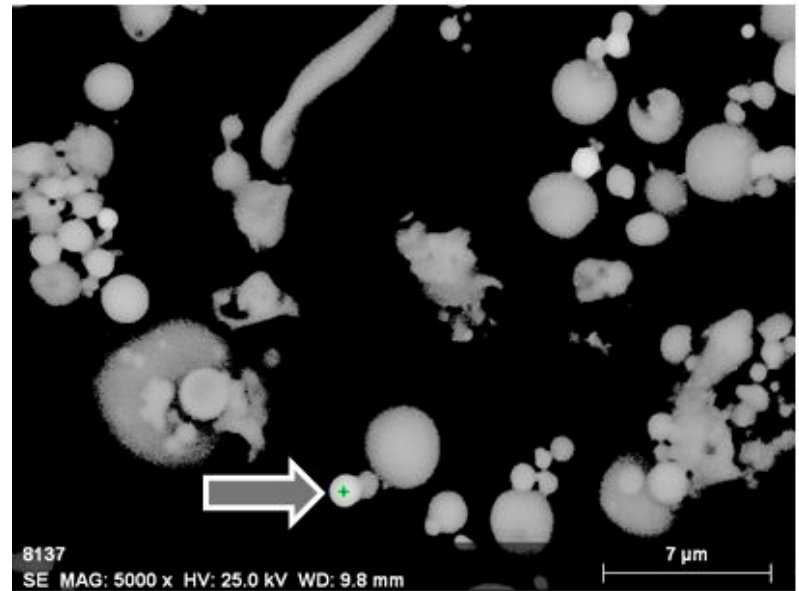

\begin{tabular}{|c|c|c|c|c|c|}
\hline Element & Series & $\begin{array}{l}\text { unn. C } \\
\text { [wt. os] }\end{array}$ & $\begin{array}{r}\text { norm. C } \\
\text { [wt. . o ] }\end{array}$ & $\begin{array}{r}\text { Atom. C } \\
\left.\text { [at. } \frac{\text { s }}{6}\right]\end{array}$ & $\begin{array}{r}\text { Error } \\
\text { [? }]\end{array}$ \\
\hline Oxygen & K-series & 29.78 & 34.71 & 59.37 & 28.9 \\
\hline Aluminium & K-series & 6.89 & 8.03 & 8.15 & 0.4 \\
\hline Silicon & K-series & 7.46 & 8.69 & 8.47 & 0.4 \\
\hline Potassium & K-series & 0.33 & 0.39 & 0.27 & 0.0 \\
\hline Calcium & K-series & 0.74 & 0.86 & 0.59 & 0.1 \\
\hline Titanium & K-series & 0.16 & 0.19 & 0.11 & 0.0 \\
\hline Iron & K-series & 40.27 & 46.92 & 23.00 & 1.1 \\
\hline Cerium & L-series & 0.18 & 0.21 & 0.04 & 0.0 \\
\hline & Total: & 85.82 & 100.00 & 100.00 & \\
\hline
\end{tabular}

Figure 2. Scanning electron microscope image of plant $\mathrm{W}$ fly ash with accompanying element analysis.

The XRD runs show the major minerals in relative concentrations. No attempt was made to separate or concentrate minerals by density or other parameters. For example, the plant W Appalachian feed coal only shows the presence of quartz and clay minerals (kaolinite and illite). The fly ash XRD patterns are dominated by glass, which, as a non-crystalline material, is represented as a broad, amorphous background pattern. Quartz and mullite were the prominent minerals in the plant W fly ash. In addition to the latter minerals, hematite and possibly lime were detected in the plant I unit 1 fly ash. Without extensive separation and concentration methods, XRD is not sensitive enough to detect trace amounts $(<<1 \mathrm{wt} \%)$ of REE-bearing and other minerals. 
Table 5. Moisture (\% as-received basis), ash ( $\%$ dry basis), major oxides ( $\%$ ash basis), minor elements (ppm, ash basis) and rare earth elements and yttrium (ppm, ash basis) for two power plants burning coal blends dominated by the Fire Clay coal.

\begin{tabular}{|c|c|c|c|c|c|c|c|c|c|c|c|c|c|c|c|c|c|c|c|c|c|c|c|}
\hline Sample & Plant & Unit & Sample Type & Moisture & Ash & $\mathrm{SiO}_{2}$ & $\mathrm{Al}_{2} \mathrm{O}_{3}$ & $\mathrm{Fe}_{2} \mathrm{O}_{3}$ & $\mathrm{CaO}$ & MgO & $\mathrm{Na}_{2} \mathrm{O}$ & $\mathrm{K}_{2} \mathrm{O}$ & $\mathbf{P}_{2} \mathrm{O}_{5}$ & $\mathrm{TiO}_{2}$ & $\mathrm{SO}_{3}$ & & & & & & & & \\
\hline 93931 & W & 1 & Feed Coal & 5.24 & 13.40 & 54.17 & 29.53 & 7.09 & 1.80 & 1.00 & 0.32 & 2.29 & 0.50 & 1.71 & 0.90 & & & & & & & & \\
\hline 93932 & W & 1 & Fly Ash & 0.19 & 96.12 & 54.21 & 28.43 & 7.60 & 4.01 & 1.07 & 0.32 & 2.26 & 0.54 & 1.60 & 0.09 & & & & & & & & \\
\hline 93933 & W & 1 & Bottom Ash & 8.29 & 100.00 & 49.96 & 28.62 & 11.54 & 3.85 & 1.13 & 0.17 & 2.12 & 0.67 & 1.20 & $<0.1$ & & & & & & & & \\
\hline 93939 & I & 1 & Feed Coal & 6.00 & 12.45 & 48.09 & 26.25 & 15.46 & 2.97 & 1.21 & 0.19 & 2.64 & 0.21 & 1.12 & 2.15 & & & & & & & & \\
\hline 93951 & I & 1 & Fly Ash & 11.24 & 95.67 & 53.47 & 29.91 & 8.46 & 1.50 & 0.82 & 0.20 & 1.81 & 0.36 & 1.72 & 0.20 & & & & & & & & \\
\hline Sample & Plant & Unit & Sample Type & $\mathbf{V}$ & $\mathbf{C r}$ & Mn & Co & $\mathrm{Ni}$ & $\mathrm{Cu}$ & $\mathbf{Z n}$ & As & $\mathbf{R b}$ & Sr & $\mathbf{Z r}$ & Mo & $\mathbf{C d}$ & Sb & Ba & $\mathbf{P b}$ & & & & \\
\hline 93931 & W & 1 & Feed Coal & 536 & 170 & 212 & 90 & 147 & 235 & 174 & 60 & 324 & 1213 & 304 & 170 & $<1$ & 6 & 1182 & 84 & & & & \\
\hline 93932 & W & 1 & Fly Ash & 486 & 156 & 223 & 82 & 137 & 181 & 177 & 73 & 355 & 1175 & 302 & 152 & 1 & 6 & 1273 & 81 & & & & \\
\hline 93933 & W & 1 & Bottom Ash & 322 & 130 & 393 & 63 & 130 & 102 & 92 & 2 & 510 & 1624 & 260 & 47 & 1 & 1 & 2198 & 76 & & & & \\
\hline 93939 & I & 1 & Feed Coal & 301 & 152 & 200 & 44 & 159 & 136 & 177 & 162 & 226 & 672 & 255 & 68 & 2 & 8 & 839 & 115 & & & & \\
\hline 93951 & I & 1 & Fly Ash & 516 & 168 & 114 & 55 & 110 & 204 & 113 & 124 & 221 & 1047 & 360 & 153 & $<1$ & 5 & 1253 & 100 & & & & \\
\hline Sample & Plant & Unit & Sample Type & $\mathbf{Y}$ & La & $\mathrm{Ce}$ & Pr & Nd & Sm & LREE & $\mathbf{E u}$ & Gd & $\mathbf{T b}$ & Dy & Ho & Er & $\mathbf{T m}$ & $\mathbf{Y b}$ & Lu & HREE & REY (1) & REY (2) & LREE/HREE \\
\hline 93931 & W & 1 & Feed Coal & 102 & 99 & 208 & 67 & 99 & 26 & 499 & 6 & 14 & 11 & 18 & 14 & 20 & 7 & 10 & 6 & 105 & 95 & 706 & 4.76 \\
\hline 93932 & W & 1 & Fly Ash & 110 & 108 & 224 & 79 & 111 & 28 & 551 & 7 & 15 & 12 & 20 & 15 & 22 & 7 & 11 & 6 & 113 & 744 & 774 & 4.85 \\
\hline 93933 & W & 1 & Bottom Ash & 123 & 114 & 247 & 84 & 128 & 33 & 606 & 8 & 19 & 12 & 21 & 2 & 20 & 6 & 12 & 8 & 108 & 834 & 837 & 5.64 \\
\hline 93939 & I & 1 & Feed Coal & 129 & 133 & 276 & 52 & 99 & 49 & 607 & 5 & 36 & 23 & 26 & 13 & 26 & 11 & 15 & 5 & 161 & 112 & 897 & 3.76 \\
\hline 93951 & I & 1 & Fly Ash & 124 & 141 & 304 & 66 & 121 & 34 & 667 & 5 & 29 & 8 & 24 & 5 & 14 & 2 & 15 & 5 & 108 & 860 & 899 & 6.18 \\
\hline
\end{tabular}

(1) ppm whole sample basis

(2) ppm ash basis 


\section{Summary}

Some Central Appalachian coals are known to be enriched in rare earth elements; the Fire Clay coal in eastern Kentucky, with a REY-enriched volcanic ash fall tonstein, is among the best-known REE source in the region. The tonstein has a greater contribution to the total coal + parting REY than would be immediately inferred from its thickness, accounting for about $20 \%-35 \%$ of the REY in the coal + parting sequence. In cases where the coal is beneficiated, much of the partings and the roof and floor rocks mined with the coal are removed from the shipped clean coal product, leaving their portion of the REY at the preparation plant. In some cases, such as seen in the Mardon and Hower [3] study, even though the tonstein is not present in the Fire Clay coal, the REY were still enriched compared to most other coal seams in the region. In this case, as well as mines that ship run-of-mine products to the utility, the shipped REY content should be virtually the same as for the mined coal. At the power plant, the delivered coal will be pulverized, generally accompanied by the elimination of some of the harder rock, before it is fired into the boiler.

The scenarios described above describe some of the constraints inherent in translating data from a whole-seam section, with or without partings, to the delivered coal at the power plant and then to the pulverized coal combusted in the boiler. The Bragg et al. [4] data for US coals generally do not include rock partings thicker than a prescribed amount, usually 0.375 inches $(0.95 \mathrm{~cm})$. For this reason and because we cannot fully account for misplaced material at the preparation plant, we must treat the geologic information as a first approximation of the bottom ash and fly ash chemistry. Therefore, the reported REY concentrations of $+/-1500$ ppm [3] for the CCP's of burn of run-of-mine, no-tonstein, high-REY Fire Clay coal actually compare favorably with the 775-900-ppm fly ashes produced by plants burning beneficiated Fire Clay coal.

\section{Acknowledgments}

Portions of this study were funded by contracts with the US Department of Energy National Energy Technology Laboratory by way of Learning Tools Interoperability® (LTI®).

\section{Author contributions}

All of the authors have had roles in one or more aspects of the study. James C. Hower and Cortland F. Eble conducted the early-1990s sampling Reference [2]. Hower conducted the Reference [3] sampling and collected samples for the Kentucky portion of Reference [4]. Hower, John G. Groppo, Kevin R. Henke, Cortland F. Eble, Wencai Zhang, and Madison M. Hood were all part of the most recent sampling efforts. James C. Hower and Madison M. Hood were responsible for petrographic data, Kevin R. Henke was responsible for the mineralogy, and Dali Qian was responsible for the microbeam studies. Rick Q. Honaker, John G. Groppo, and Wencai Zhang were responsible for processing of the fly ash. Basically, this is a three-organization effort within the university and all authors have been part of the various discussions that underlie this contribution.

\section{Conflicts of Interest}

The authors declare no conflict of interest. 


\section{References}

1. Bohor, B.F.; Triplehorn, D.M. Volcanic origin of the flint clay parting in the Hazard No. 4 (Fire Clay) coal bed of the Breathitt Formation in eastern Kentucky. In Coal and Coal-Bearing Rocks of Eastern Kentucky, Annual Geological Society of America Coal Division Field Trip: Kentucky Geological Survey, Ser. 11; Cobb, J.C., Chesnut, D.R., Jr., Hester, N.C., Hower, J.C., Eds.; University of Kentucky: Lexington, KY,USA, 1981; pp. 49-54.

2. Hower, J.C.; Ruppert, L.F.; Eble, C.F. Lanthanide, Yttrium, and Zirconium anomalies in the Fire Clay coal bed, Eastern Kentucky. Int. J. Coal Geol. 1999, 39, 141-153.

3. Mardon, S.M.; Hower, J.C. Impact of coal properties on coal combustion by-product quality: Examples from a Kentucky power plant. Int. J. Coal Geol. 2004, 59, 153-169.

4. Bragg, L.J.; Oman, J.K.; Tewalt, S.J.; Oman, C.L.; Rega, N.H.; Washington, P.M.; Finkelman, R.B. U.S. Geological Survey Coal Quality (COALQUAL) Database: Version 2.0; U.S. Geological Survey Open-file Report 97-134; U.S. Geological Survey: Denver, CO, USA, 1998.

5. Seredin, V.V.; Dai, S. Coal deposits as potential alternative sources for lanthanides and yttrium. Int. J. Coal Geol. 2012, 94, 67-93.

6. Hower, J.C.; Dai, S.; Seredin, V.V.; Zhao, L.; Kostova, I.J.; Silva, L.F.O.; Mardon, S.M.; Gurdal, G. A note on the occurrence of Yttrium and Rare Earth Elements in coal combustion products. Coal Combust. Gasif. Prod. 2013, 5, 39-47.

7. Dai, S.; Seredin, V.V.; Ward, C.R.; Jian, J.; Hower, J.C.; Song, X.; Jiang, Y.; Wang, X.; Gornostaeva, T.; Liu, H.; et al. Composition and modes of occurrence of minerals and elements in coal combustion products derived from high-Ge coals. Int. J. Coal Geol. 2014, 121, 79-97.

8. Meier, A.L.; Lichte, F.E.; Briggs, P.H.; Bullock, J.L. Analysis of coal ash by inductively coupled plasma emissionspectroscopy and inductively coupled plasma-Mass spectroscopy. In Analytical Methods Manual for the Mineral Resource Surveys Program, U.S. Geological Survey; Arbogast, B.F., Ed.; U.S. Geological Survey Open File 96-525; U.S. Geological Survey: Denver, CO, USA, 1996; pp. 109-125.

9. International Committee for Coal Petrology (ICCP). The new vitrinite classification (ICCP System 1994). Fuel 1998, 77, 349-358.

10. International Committee for Coal Petrology (ICCP). The new inertinite classification (ICCP System 1994). Fuel 2001, 80, 459-471.

11. Hower, J.C. Petrographic examination of coal-combustion fly ash. Int. J. Coal Geol. 2012, 92, 90-97.

12. Hower, J.C.; Groppo, J.G.; Joshi, P.; Dai, S.; Moecher, D.P.; Johnston, M.N. Location of Cerium in Coal-combustion Fly Ashes: Implications for Recovery of Lanthanides. Coal Combust. Gasif. Prod. 2013, 5, 73-78.

(C) 2015 by the authors; licensee MDPI, Basel, Switzerland. This article is an open access article distributed under the terms and conditions of the Creative Commons Attribution license (http://creativecommons.org/licenses/by/4.0/). 